\title{
Synthesis of Isolaurene and Its Related Compounds from Cyclotene
}

\author{
Kennosuke Tonari, Itsuo ICHIMoto and Hiroo UEDA \\ Department of Agricultural Chemistry, College of Agriculture, \\ University of Osaka Prefecture, Sakai, Osaka, Japan \\ Received October 8, 1979
}

\begin{abstract}
Novel syntheses of isolaurene (1), an isomer of laurene (2) found in algae, and its related compounds were performed from cyclotene (3). Benzylated cyclotene (4) was allowed to react with p-tolyl-magnesium bromide to give 5-methyl-2-p-tolyl-2-cyclopentenone (6). Hydrogenation of 6 over palladium charcoal, followed by methylation with one equivalent of methyl iodide gave 2,5-dimethyl-2-p-tolyl-cyclopentanone (8), whereas treatment with 3 equivalents of methyl iodide gave 2-p-tolyl-2, 5, 5-trimethylcyclopentane (10). Both $\mathbf{8}$ and $\mathbf{1 0}$ were treated with a large excess of methyl lithium to afford the corresponding alcohols (9) and (11), dehydration of which, in an acidic medium, gave 1 and 1-methylene-2-p-tolyl-2, 5, 5-trimethylcyclopentane (12), respectively. Compound 10 is a structural isomer of cuparenone (15) found in the wood of an Indian plant.
\end{abstract}

Isolaurene $\mathbf{1}$, an isomer of laurene $\mathbf{2}$ which is the sesquiterpene hydrocarbon in some algae (Laurencia glandulifera Kutzing and Laurencia nipponica Yamada), has been well described by Irie $^{1)}$ and McMurry ${ }^{2)}$ in the discussion of the structural elucidation of 2 .

For the synthesis of $\mathbf{1}$, a lengthy route including a tedious reaction was involved, when cyclopentanone was chosen as starting material. ${ }^{1)}$ However, if cyclotene 3 , used as a artificial flavor in various food items, is employed for the synthesis of $\mathbf{1}$, a simple and short route is expected.

The purpose of this report is to describe a simple synthesis of $\mathbf{1}$ and its related compounds $\mathbf{1 0}$ and $\mathbf{1 2}$, from easily available $\mathbf{3}$, as depicted in Scheme 1.

Benzylation of 3 with benzyl chloride and potassium hydroxide in methanol under reflux afforded 4 with a yield of $80 \%$. Compound 4 was allowed to react with Grignard reagent prepared from an equivalent amount of magnesium and $p$-bromotoluene in ether for $10 \mathrm{hr}$ at room temperature, followed by acidification to give a $1: 1$ mixture of 5 and $6,78 \%$ yield. This suggests that the reaction may proceed via tolylation of $\mathbf{3}$ and $\mathbf{4}$, followed by spontaneous elimination of benzyl alcohol to give 5 and 6. When 3 was directly treated with 2 equivalents of Grignard reagent, the yield of 5 and 6 was only $15 \%$, leading to the suspicion that the magnesium complex of $\mathbf{3}$ is more insoluble than that of $\mathbf{4}$ in ether.

In order to obtain pure 6 with a good yield, the conversion from 5 to $\mathbf{6}$ was examined under various conditions as shown in Table I. The best yield was obtained by heating under reflux with toluene containing $p$-toluenesulfonic acid as a catalyst, using an azeotropic water removal system (Dean-Stark trap). Compound 6 thus obtained was further purified by silica-gel column chromatography. Catalytic hydrogenation of 6 over palladium charcoal afforded 7 which showed a single peak on GLC. However, 7 appeared as two spots on TLC suggesting the possibility of two diastereomers, $7 \mathbf{a}$ and $\mathbf{7 b}$. In the NMR spectrum the methyl protons in $7 \mathrm{a}(1.06 \mathrm{ppm})$ are shifted slightly higher field than those in $7 \mathrm{~b}(1.12 \mathrm{ppm})$ because of the anisotropic effect of the carbonyl group.

The alkylation of 7 with methyl iodide in THF using an equimolar amount of sodium hydride at room temperature afforded a mixture of two products showing almost only one spot on TLC. Distillation of the products gave a mixture showing two peaks ( $R t=4.2$, $4.4 \mathrm{~min}$ ) on GLC, $55 \%$ yield. The GC-MS 
<smiles>CC1=C(C)C(C)([Te]P)CC1</smiles><smiles>C=C1CCC(C)([Ge])C1C</smiles>

(2)<smiles></smiles>

(15)

Fig. 1.
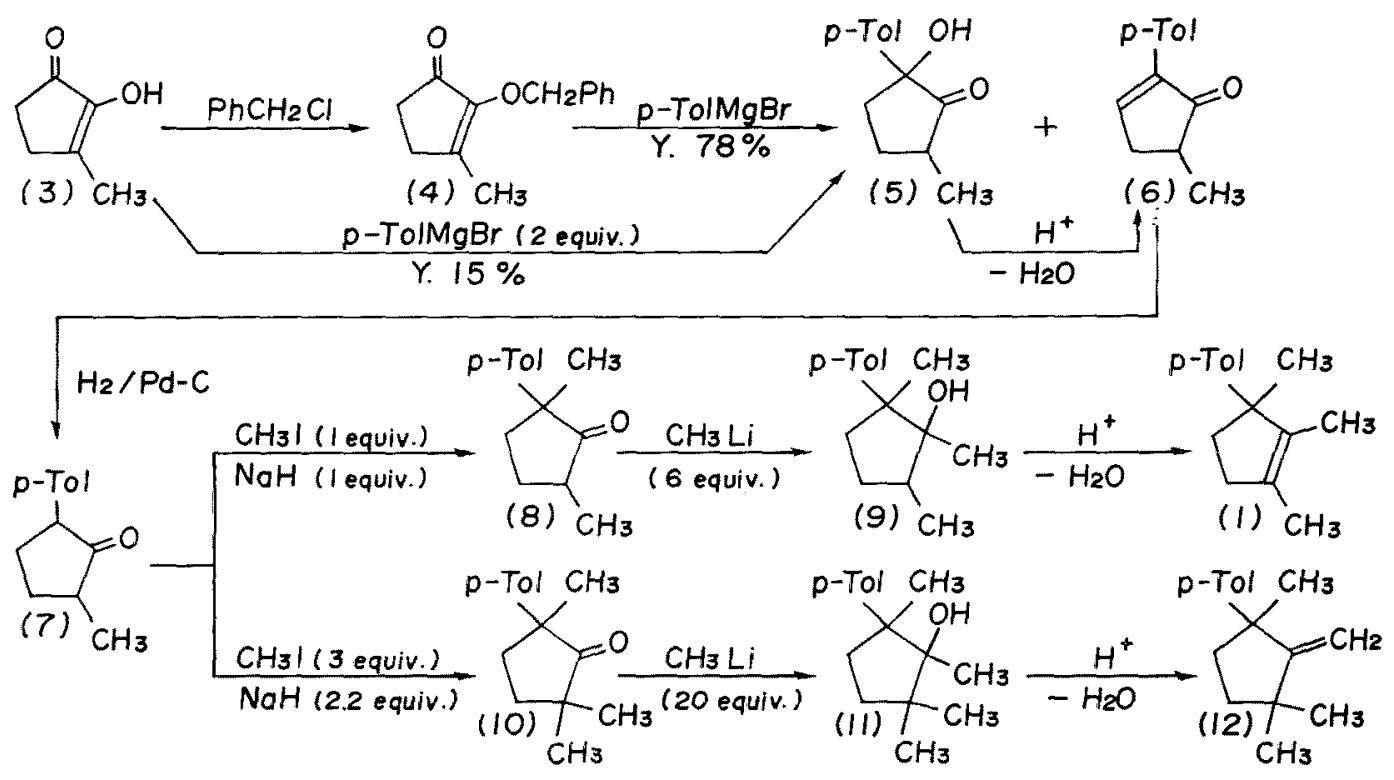

Scheme 1

TABLE I. CONYERSION OF 2-HYDROXY-5-METHYL2-p-TOLYLCYCLOPENTANONE (5) TO 5-METHYL2-p-TORYL-2-CYCLOPENTENONE (6) BY DEHYDRATION UNDER VARIOUS CONDITIONS

\begin{tabular}{clc}
\hline Expt, run & Reaction conditions & $\begin{array}{c}\text { Conversion } \\
(\%)\end{array}$ \\
\hline 1 & $20 \% \mathrm{HCl}$ reflux & 30 \\
2 & $p-\mathrm{TsOH} /$ toluene reflux & 80 \\
3 & $(\mathrm{COOH})_{2}$ at $\left.180^{\circ} \mathrm{C}^{4}\right)$ & 50 \\
4 & Pyridine-SOCl & at $0 \sim 20^{\circ} \mathrm{C}^{6}$ \\
\hline
\end{tabular}

spectra of these products showed the molecular weight to be 202 and indicated that the products consisted of two diastereomers of $\mathbf{8}(\mathbf{8 a}$ and $\mathbf{8 b})$ or one diastereomer $(\mathbf{8 a}$ or $\mathbf{8 b})$ and another possible compound, 14. This was synthesized from $\mathbf{6}$ as shown in Scheme 2.

Moreover, there was no evidence from the physical properties determined from TLC, GLC, IR and NMR for the presence of $\mathbf{1 4}$ in the methylated product of 7 . Therefore, the two peaks on GLC were assigned to the dia- stereomers $\mathbf{8 a}$ and $\mathbf{8 b}$.

The mixture of $\mathbf{8 a}$ and $\mathbf{8 b}$ was treated with an excess of methyl lithium to give a mixture of the possible diastereomers 9. Purification of the products using silica-gel column chromatography and preparative TLC afforded mainly two products having $R f 0.7$ and 0.6 on TLC. These products showed the same retention time on GLC and similar patterns in the IR and NMR spectra. When they were refluxed in methanol containing a trace amount of hydrochloric acid, however, a single product 1 was obtained with a good yield. This can be well explained by the assumption that a water molecule was eliminated from 9 to form the possible product 1. Spectroscopic data of $\mathbf{1}$ thus obtained were in clear accordance with the reported data. ${ }^{1}$

On the other hand, 7 was treated with 3 equivalents of methyl iodide and 2.2 equivalents of sodium hydride to afford trimethyl com- 
<smiles>CC1CCC([Te])C1=O</smiles><smiles>CC1CCC([Te])C1=O</smiles><smiles>CC1CCC(C)([Te]P)C1=O</smiles>

(8a)<smiles>C[C@H]1CCC(C)([18OH])C1=O</smiles>

(8b)

Fig. 2.
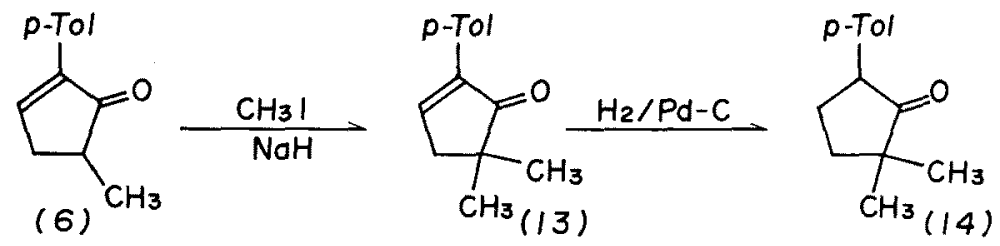

Scheme 2

pound 10, which is the structural isomer of cuparenone $\mathbf{1 5}$ found in the essential oil from the wood of an Indian plant. ${ }^{6,7)}$ Further methylation of $\mathbf{1 0}$ with an excess of methyl lithium gave 11, and subsequent dehydration by acid treatment afforded hydrocarbon $\mathbf{1 2}$, corresponding to the structural isomer of 1 .

\section{EXPERIMENTAL PROCEDURES}

Infrared spectra were taken with a JASCO IRA-2 spectrometer. Nuclear magnetic resonance spectra were recorded with a JNM MH-60 spectrometer. Mass spectra were measured with a Hitachi RUM-6MG instrument.

2-Benzyloxy-3-methyl-2-cyclopentenone (4). To a stirred mixture of cyclotene (3) $(22.4 \mathrm{~g}, 0.2 \mathrm{~mol})$ and potassium hydroxide $(12.4 \mathrm{~g}, 0.22 \mathrm{~mol})$ in $150 \mathrm{ml}$ of methanol was added benzyl chloride $(30.4 \mathrm{~g}, 0.24 \mathrm{~mol})$ and then the mixture was refluxed for $3 \mathrm{hr}$. After removal of the solvent, the residue was extracted with ether; the extract was washed successively with $5 \%$ aqueous sodium hydroxide, water and brine, and dried over $\mathrm{Na}_{2} \mathrm{SO}_{4}$. The ether solution was concentrated, and the residue was distilled in vacuo to afford $31 \mathrm{~g}$ of 4, bp $134 \sim 138^{\circ} \mathrm{C} / 3 \mathrm{~mm}$. IR $\nu_{\max } \mathrm{cm}^{-1}: 2900,1690$, $1640,1490,1440,1390,1330,1200,1100,740$. NMR $\delta_{\max }^{\mathrm{CCl}_{4}} \mathrm{ppm}: 1.8(3 \mathrm{H}, \mathrm{s}), 2.24(4 \mathrm{H}, \mathrm{s}), 5.15(2 \mathrm{H}, \mathrm{s}), 7.25$ $(5 \mathrm{H}, \mathrm{s})$. MS m/e: $202\left(\mathrm{M}^{+}\right), 111,91$.

2-Hydroxy-5-methyl-2-p-tolylcyclopentanone (5) and 5-methyl-2-p-tolyl-2-cyclopentenone (6). To stirred Grignard reagent prepared from $\mathrm{Mg}(3.9 \mathrm{~g}, 0.16 \mathrm{~mol})$ and $p$-bromotoluene $(27.4 \mathrm{~g}, 0.16 \mathrm{~mol})$ in $50 \mathrm{ml}$ of ether was added $4(24.2 \mathrm{~g}, 0.1 \mathrm{~mol})$ in $50 \mathrm{ml}$ of ether dropwise and the mixture was stirred for $10 \mathrm{hr}$ at room temperature. The reaction mixture was treated with cold diluted hydrochloric acid and the ether layer was washed with water and brine, and then dried over $\mathrm{Na}_{2} \mathrm{SO}_{4}$. After removal of the solvent, the residue was distilled in vacuo to afford $10 \mathrm{~g}$ of benzyl alcohol, bp $103 \sim 108^{\circ} \mathrm{C} / 20 \mathrm{~mm}$ and $18.3 \mathrm{~g}(78.2 \%)$ of a $1: 1 \mathrm{mix}-$ ture of 5 and 6 as a colorless oil, bp $125 \sim 133^{\circ} \mathrm{C} / 3 \mathrm{~mm}$.

The above-mentioned mixture (5 and 6) with $p$ toluenesulfonic acid monohydrate in $150 \mathrm{ml}$ of toluene was refluxed under stirring using a Dean-Stark trap for $9 \mathrm{hr}$. After removal of the solvent, the resulting mixture was extracted with $200 \mathrm{ml}$ of ether and washed with $5 \%$ aqueous sodium hydroxide, water and brine, and then dried over $\mathrm{Na}_{2} \mathrm{SO}_{4}$. Distillation in vacuo gave $12 \mathrm{~g}$ of 6 (purity; $90 \%$ ), bp $143 \sim 150^{\circ} \mathrm{C} / 3 \mathrm{~mm}$. Compound 6 thus obtained was subjected to silicagel column chromatography with hexane-ether $(75: 25)$ giving $9 \mathrm{~g}$ of pure 6. IR $\nu_{\max } \mathrm{cm}^{-1}: 2900,1700,1600$, $1505,1440,1300,800$. NMR $\delta_{\max }^{\mathrm{CCl}_{4}} \mathrm{ppm}: 1.22(3 \mathrm{H}$, $\mathrm{d}, J=7 \mathrm{~Hz}), 2.33(3 \mathrm{H}, \mathrm{s}), 77.8(5 \mathrm{H}, \mathrm{m})$. MS $\mathrm{m} / \mathrm{e}$ : $186\left(\mathrm{M}^{+}\right), 171,157,143,127,117$.

5-Methyl-2-p-tolylcyclopentanone (7). A solution of $6(3.7 \mathrm{~g}, 0.02 \mathrm{~mol})$ in $50 \mathrm{ml}$ of methanol was shaken under $1 \mathrm{~atm}$ of hydrogen with $5 \%$ palladium on carbon until 1 equivalent of hydrogen was absorbed (ca. $2 \mathrm{hr}$ ). After removal of the solvent and catalyst, the residue was distilled in vacuo to afford $3.6 \mathrm{~g}$ of 7 as a colorless oil, bp $142 \sim 147^{\circ} \mathrm{C} / 4 \mathrm{~mm}$. GLC: single peak $R t=$ $2.8 \mathrm{~min}\left(\mathrm{OV}-1,150-200^{\circ} \mathrm{C}\right.$, programmed $\left.8^{\circ} \mathrm{C} / \mathrm{min}\right)$. TLC: two spots, $R f=0.44$ and 0.52 [silica-gel, hexaneether $(9: 1)] . \quad$ IR $\nu_{\max } \mathrm{cm}^{-1} ; 2950,2850,1740,1500$, 1450, 1140, 800. NMR $\hat{\delta}_{\max }$ ppm: $1.06(7 \mathrm{a}), 1.12(7 \mathrm{~b})$. $(3 \mathrm{H}, \mathrm{d}, J=7 \mathrm{~Hz}), 2.30(3 \mathrm{H}, \mathrm{s}), 7.17 .2(4 \mathrm{H}, \mathrm{s}) . \quad \mathrm{MS} m / e$ : $188\left(\mathrm{M}^{+}\right), 173,145,131,117$.

2,5-Dimethyl-2-p-tolylcyclopentanone (8). To a sus- 
pension of sodiurn hydride $(0.38 \mathrm{~g}$ of a $50 \%$ dispersion in mineral oil; $8 \mathrm{mmol}$ ) in $20 \mathrm{ml}$ of THF was added 7 $(1.5 \mathrm{~g}, 8 \mathrm{mmol})$ dropwise, and the mixture was cooled in an ice-bath for $10 \mathrm{~min}$ with rechanical stirring. To this reaction mixture was added methyl iodide $(1.4 \mathrm{~g}$, $10 \mathrm{mmol}$ ) and the resulting mixture was kept for $3 \mathrm{hr}$ below $15^{\circ} \mathrm{C}$. After removal of the solvent, the residue was extracted with ether and the ether extract was washed with $5 \%$ aqueous sodium hydroxide, water and brine, and then dried over $\mathrm{Na}_{2} \mathrm{SO}_{4}$. Distillation in vacuo gave $0.8 \mathrm{~g}$ of a $1: 1$ mixture of $8 \mathrm{a}$ and $8 \mathrm{~b}$, bp $125 \sim$ $130^{\circ} \mathrm{C} / 6 \mathrm{~mm}$ GC-MS $m / e: R t=4.2 ; 202\left(\mathrm{M}^{+}\right), 187$, $175,159,145,132,117, R t=4.4 ; 202\left(\mathrm{M}^{+}\right), 187,175$, $159,145,132,117$. TLC: single spot $R f=0.6$ [silicagel, hexane-ether $(9: 1)]$ IR $\nu_{\text {max }} \mathrm{cm}^{-1}: 2950,2870$, $1730,1500,1450,1370,820$. NMR $\delta_{\max }^{\mathrm{CCl}_{4}} \mathrm{ppm}$ : $1.02(8 \mathrm{a})$ and $1.13(8 \mathrm{~b})(3 \mathrm{H}, \mathrm{d}, J=7 \mathrm{~Hz}), 1.3(3 \mathrm{H}, \mathrm{s})$, $2.35(3 \mathrm{H}, \mathrm{s}), 7.27 .3(4 \mathrm{H}, \mathrm{s})$

2-p-Tolyl-1, 2, 5-trimethyl-cyclopentanol (9). To a stirred solution of methyl lithium prepared from $\mathrm{Li}$ $(0.3 \mathrm{~g}, 40 \mathrm{mmol})$ and methyl iodide $(2.8 \mathrm{~g}, 20 \mathrm{mmol})$ in $30 \mathrm{ml}$ of ether was added $8(0.6 \mathrm{~g}, 3 \mathrm{mmol})$ dropwise at $0 \sim 5^{\circ} \mathrm{C}$. The mixture was stirred for $10 \mathrm{hr}$ at room temperature, and then quenched by the addition of saturated ammonium chloride solution. The separated ether layer was subjected to silica-gel column chromatography [hexane-ether $(9: 1)$ ] to give $0.3 \mathrm{~g}$ of 9 as a colorless oil, which was further purified by preparative TLC, developed with the same solvent system as used for the column chromatography. The two zones of $R f=0.7$ and 0.6 on TLC were collected separately and eluted with ether to afford $0.05 \mathrm{~g}$ and $0.1 \mathrm{~g}$ of an oil, respectively. 9 having $R f=0.7$; IR $\nu_{\max } \mathrm{cm}^{-1}: 3600,2930$, $1500,1450,1370,1180,920,810$. NMR $\delta_{\mathrm{max}}^{\mathrm{CCl}} \mathrm{ppm}$ : $1.0(3 \mathrm{H}, \mathrm{d}, J=7 \mathrm{~Hz}), 1.06(3 \mathrm{H}, \mathrm{s}), 1.35(3 \mathrm{H}, \mathrm{s}), 2.35$ $(3 \mathrm{H}, \mathrm{s}), 7.0 \sim 7.5(4 \mathrm{H}, \mathrm{m})$. MS $m / e: 218\left(\mathrm{M}^{+}\right), 200$, $185,171,146,133,119$. 9 having $R f=0.6 ; \mathrm{IR} \nu_{\max } \mathrm{cm}^{-1}$ : $3550,2950,1510,1440,1380,1160,1120,1090,810$. NMR $\hat{o}_{\mathrm{max}}^{\mathrm{CCl}_{4}} \mathrm{ppm}: 1.0(3 \mathrm{H}, \mathrm{d}, J=7 \mathrm{~Hz}), 1.07(3 \mathrm{H}, \mathrm{s})$, $1.35(3 \mathrm{H}, \mathrm{s}), 2.28(3 \mathrm{H}, \mathrm{s}), 7.0 \sim 7.5(4 \mathrm{H}, \mathrm{m})$. MS $m / e$ : $218\left(\mathrm{M}^{+}\right), 185,171,157,146,133,117$.

2-p-Tolyl-1, 2, 5-trimethyl-5-cyclopentene (Isolaurene) (1). i) A solution of $30 \mathrm{mg}$ of $9(R f=0.7) \mathrm{in}$ methanol containing a trace amount of conc. hydrochloric acid was refluxed for $1 \mathrm{hr}$. After removal of the solvent, the residue was extracted with ether, and then the usual work-up afforded $15 \mathrm{mg}$ of pure 1 . IR $\nu_{\max } \mathrm{cm}^{-1}$ : $2900,1510,1440,1370,810$. NMR o $o_{\max }^{\mathrm{Cc1}} \mathrm{ppm}: 1.36$ $(6 \mathrm{H}, \mathrm{s}), 1.75(3 \mathrm{H}, \mathrm{s}), 7.06(4 \mathrm{H}, \mathrm{s})$. MS m/e: $200\left(\mathrm{M}^{+}\right)$, $185,171,158,143$.

ii) One-tenth of $9(R f=0.6)$ was treated as described above to afford $70 \mathrm{mg}$ of 1 . This product was identical in all respects (IR, NMR and MS spectra) with that obtained in experiment i).
The spectroscopic data of $\mathbf{1}$ agreed also with those reported by Irie et al. ${ }^{\text {) }}$.

2-p-Tolyl-2, 5, 5-trimethylcyclopentanone (10). To a stirred suspension of sodium hydride $(0.42 \mathrm{~g}$ of a $50 \%$ dispersion in mineral oil, $9 \mathrm{mmol}$ ) in $10 \mathrm{ml}$ of THF was added $7(0.75 \mathrm{~g}, 4 \mathrm{mmol})$ dropwise at $0 \sim 5^{\circ} \mathrm{C}$ for $15 \mathrm{~min}$. To this mixture was added methyl iodide $(1.7 \mathrm{~g}, 12 \mathrm{~m}$ mol) and the mixture was stirred for $4 \mathrm{hr}$ at room temperature. The usual work-up gave $\mathbf{1 0}$ as a colorless oil, bp $98 \sim 102^{\circ} \mathrm{C} / 3 \mathrm{~mm}$. IR $\nu_{\max } \mathrm{cm}^{-1}: 2950,2860$, $1735,1510,1460,1380,1020,820$. NMR $\delta_{\max }^{\mathrm{CCl} 1_{4}} \mathrm{ppm}$ : $0.9(3 \mathrm{H}, \mathrm{s}), 1.05(3 \mathrm{H}, \mathrm{s}), 1.3(3 \mathrm{H}, \mathrm{s}), 2.25(3 \mathrm{H}, \mathrm{s}), 6.9 \sim$ $7.0(4 \mathrm{H}, \mathrm{m})$. MS m/e: $216\left(\mathrm{M}^{+}\right), 201,188,173,159$, $144,132$.

1,2,5,5-Tetramethyl-2-p-tolylcyclopentanol (11). To a stirred solution of methyl lithium prepared from $\mathrm{Li}$ $(0.7 \mathrm{~g}, 0.1 \mathrm{~mol})$ and methyl iodide $(7.1 \mathrm{~g}, 0.05 \mathrm{~mol})$ in $20 \mathrm{ml}$ of ether was added $10(0.43 \mathrm{~g}, 2 \mathrm{mmol})$ dropwise at $0 \sim 5 \% \mathrm{C}$. After stirring for $30 \mathrm{hr}$ at room temperature, the reaction was quenched by the addition of saturated ammonium chloride solution. The ether layer was separated and condensed in yacuo, the residue was purified by silica-gel column chromatography and preparative TLC to give $0.45 \mathrm{~g}$ of pure 11 . IR $\nu_{\max } \mathrm{cm}^{-1}$ $3600,2950,1510,1450,1370,810$. NMR $\delta_{m a x}^{\mathrm{CCl} l_{4}} \mathrm{ppm}$ : $0.95(3 \mathrm{H}, \mathrm{s}), 1.05(6 \mathrm{H}, \mathrm{s}), 1.35(3 \mathrm{H}, \mathrm{s}), 7.0 \sim 7.3(4 \mathrm{H}, \mathrm{s})$, MS m/e: $232\left(\mathrm{M}^{+}\right), 214,199,189,171,145,132,112$.

1-Methylene-2-p-tolyl-2,5,5-trimethylcyclopentane (12). Dehydration of $\mathbf{1 1}$ was similarly conducted as described for the preparation of 1 . A solution of 11 (150 $\mathrm{mg}, 0.65 \mathrm{mmol}$ ) in methanol containing a few drops of conc. hydrochloric acid was refluxed for $2 \mathrm{hr}$. After removal of the solvent, the residue was extracted with ether and the extract was washed with $5 \%$ aqueous sodium carbonate and brine, and then dried over $\mathrm{Na}_{2} \mathrm{SO}_{4}$. After evaporation of the solvent, the residue was purified by TLC to afford $100 \mathrm{mg}$ of pure 12 . IR $\nu_{\max } \mathrm{cm}^{-1} ; 2950,1510,1450,1360,810$. NMR $\hat{\partial}_{\mathrm{max}}^{\mathrm{Col}_{4}} \mathrm{ppm}: 1.03(6 \mathrm{H}, \mathrm{s}), 1.3(3 \mathrm{H}, \mathrm{s}), 2.36(3 \mathrm{H}, \mathrm{s})$, $5.56 \sim 5.6(2 \mathrm{H}, \mathrm{m}), 7.1(4 \mathrm{H}, \mathrm{m})$. MS m/e: $214\left(\mathrm{M}^{+}\right)$, $199,185,171,156,143,132,119$.

5, 5-Dimethyl-2-p-tolyl-2-cyclopentenone (13). To a stirred suspension of sodium hydride $(290 \mathrm{mg}$ of a $50 \%$ dispersion in mineral oil, $6 \mathrm{mmol}$ ) in $15 \mathrm{ml}$ of THF was added 6 (930 $\mathrm{mg}, 5 \mathrm{mmol})$ dropwise at $0 \sim 5^{\circ} \mathrm{C}$ for 15 min. To this mixture was added methyl iodide $(1.4 \mathrm{~g}$, $10 \mathrm{mmol}$ ) and the mixture was stirred for $2.5 \mathrm{hr}$ at room temperature. After removal of the solvent, the residue was extracted with ether. The extract was dried and evaporated and the residue was distilled in vacuo to afford $150 \mathrm{mg}$ of 13 as a colorless oil, bp $105 \sim$ $107^{\circ} \mathrm{C} / 3 \mathrm{~mm}, \operatorname{mp~} 85 \sim 87^{\circ} \mathrm{C}$. IR $\nu_{\max }^{\mathrm{KBr}} \mathrm{cm}^{-1}: 2900,1690$, 
$1600,1500,1460,1430,1300,820 . \mathrm{NMR} \nu_{\max }^{\mathrm{COl}_{4}} \mathrm{ppm}$ : $1.12(6 \mathrm{H}, \mathrm{s}), 2.3(3 \mathrm{H}, \mathrm{s}), 6.9 \sim 7.6(5 \mathrm{H}, \mathrm{m})$.

5, 5-Dimethyl-2-p-tolylcyclopentanone (14). A solution of $13(0.2 \mathrm{~g}, 1 \mathrm{mmol})$ in $30 \mathrm{ml}$ of methanol was hydrogenated with $0.3 \mathrm{~g}$ of $5 \%$ palladium on carbon by the same procedure used for the hydrogenation of 6 . After removal of the solvent and catalyst, the residue was purified by silica-gel column chromatography to yield $0.15 \mathrm{~g}$ of pure 14. IR $\nu_{\max } \mathrm{cm}^{-1}: 2960,1740$, $1600,1510,1450,1260,1060,800$. NMR $\delta_{\max }^{\mathrm{CCl}_{4}} \mathrm{ppm}$ : $0.95(3 \mathrm{H}, \mathrm{s}), 1.1(3 \mathrm{H}, \mathrm{s}), 2.28(3 \mathrm{H}, \mathrm{s}), 6.85(4 \mathrm{H}, \mathrm{s})$. MS $m / e: 202\left(\mathrm{M}^{+}\right), 187,157,142,131,118$.

Acknowledgments. The authors wish to thank Shiono Koryo Co. Ltd., for the gift of cyclotene.

\section{REFERENCES}

1) T. Irie, T. Suzuki, Y. Yasunari, E. Kurosawa and T. Masamune, Tetrahedron, 25, 459 (1969).

2) J. E. McMurry and L. A. von Beroldingen, ibid., 30, 2027 (1974).

3) K. Tonari, I. Ichimoto, H. Ueda and C. Tatsumi, Nippon Nógeikagaku Kaishi, 44, 46 (1970).

4) R. B. Carlin and D. A. Constantine, J. Am. Chem. Soc., 69, 50 (1947).

5) J. S. Lomas, D. S. Sagatys and J. E. Dubois, Tetrahedron Lett., 599 (1971).

6) G. L. Chetty and Sukh Dev, ibid., 73, (1964).

7) Y. Hayakawa, F. Shimizu and R. Noyori, ibid., 993 (1978). 